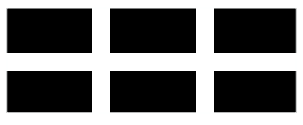

ThE William DAVIDSON INSTITUTE AT THE UNIVERSITY OF MICHIGAN BUSINESS SCHOOL

Which entrepreneurs expect to expand their businesses? Evidence from survey data in Lithuania

\author{
By: Ruta Aidis and Tomasz Mickiewicz
}

William Davidson Institute Working Paper Number 723

October 2004 


\title{
Which entrepreneurs expect to expand their businesses? Evidence from survey data in Lithuania
}

\author{
Ruta Aidis* \\ SSEES, University College London \\ Faculty of Economics and Econometrics, University of Amsterdam \\ Tomasz Mickiewicz ${ }^{* *}$ \\ SSEES, University College London
}

\begin{abstract}
This paper presents an empirical study based on a survey of 399 small and medium size companies in Lithuania. Applying bivariate and ordered probit estimators, we investigate why some business owners intend to expand their firms, while others do not. Our main findings provide evidence that the characteristics of the owners matter. Those with higher education and 'learning by doing' attributes either through previous job experience or additional entrepreneurial experience are more likely to expand their businesses. In addition, the model implications include that the intentions to expand are correlated with exporting and with size of the enterprise: medium and small size companies are more likely to grow than micro enterprises and self-employed entrepreneurs. We also analyse the link between the main perceptions of constraints to business activities and growth expectations and find that the factors, which are perceived as main business barriers, are not necessary those, which are associated with low growth expectations. In particular, perceptions of both corruption and of inadequate tax systems are main barriers to growth.
\end{abstract}

Keywords: SME, Employment, Human Capital, Taxes, Corruption

JEL classification: P37, D21, L21

* SSEES, University College London, Senate House, Malet St., London WC1E 7HU, U.K. email: R.Aidis@ssees.ucl.ac.uk

${ }^{* *}$ SSEES, University College London, Senate House, Malet St., London WC1E 7HU, U.K. email: T.Mickiewicz@ssees.ucl.ac.uk 


\section{Introduction}

For most countries in Central and Eastern Europe, the transition process has been well underway for over fourteen years. In May 2004, ten of these countries joined the European Union On the surface, these countries have developed a private sector that in terms of size and economic importance reflects the levels observed in advanced Western economies. However, a closer look shows that the composition of the private sector has been different. Whereas in transition countries most of the private sector emerged due to a shift of resources from state to private hands (through privatisation), in advanced western countries, the private sector emerged through the development of privately-owned enterprises (Pissarides 2004). Regardless of this difference, the development of a healthy small and medium-sized enterprise (SME) sector is of special importance in transition countries not only for their wealth and job generation possibilities, but also for their ability to foster innovation, experimentation and adaptation in the business environment.

In this paper, we focus on the factors affecting enterprise growth in the transition country context. We use a data sample based on a survey of 399 SME owners in Lithuania. Lithuania provides an excellent example of a transition country that has successfully transformed its status from a centrally planned Soviet republic to a fast-growing, sovereign, market-oriented and democratic EU member state. We are specifically interested in the factors affecting two types of growth expectations: intention to increase the number of employees and intention to increase business turnover. Though growth expectations might be viewed as a subjective assessment, a number of authors have indicated that business growth is at least partially determined by the entrepreneur's motivations and intentions for the business (Bird, 1988; Davidsson, 1991; Kolvereid, 1992; Cooper, 1993; Herron and Robinson, 1993; Cliff, 1998; Wiklund et al., 2003). In addition, by asking entrepreneurs about their expectations about the future, we alleviate the problem of endogeneity, unlike the typical situation where growth indicators are explained by some contemporary characteristics of firms.

In our analysis, we incorporate a set of explanatory variables including human capital measures, firm level attributes, sectoral affiliation and export behaviour. In addition, we include perceptions of the main external barriers, i.e. taxes and corruption into account as they may have an influence on growth expectations.

Our study provides the following contributions. Firstly, our data is unusually rich in its representation of both micro enterprises and self-employed entrepreneurs. This allows us to more accurately compare the effect of firm size on growth aspirations for all SME size categories. Our results indicate that while small and medium firms expect to grow, the smallest 
firms i.e. micro firms do not; thus there seems to be a stagnant pool of very small enterprises. This finding contradicts a negative link between size and employment growth found in other studies (Faggio and Konings 2003; Bechetti and Trovato 2002) We argue that the discrepancy stems from the fact that the smallest firms are being typically underrepresented in other studies $^{1}$. Secondly, we are able to test the effect of the two most significant business barriers on growth aspirations. Here we find that both the high level of taxes as well as corruption are identified as negatively related to growth aspirations. Thirdly, the characteristics of the owners matter. Those with higher education and 'learning by doing' attributes either through previous job experience or additional entrepreneurial experience are more likely to expand their businesses.

This paper is organised as follows. Section 2 examines the business environment in Lithuania and places it in the context of economic transition. Section 3 extends the discussion to the theoretical settings and presents some empirical results by other authors. Section 4 describes the survey and resulting sample of entrepreneurs. Section 5 presents the variables used in our estimation model and Section 6 presents our results. Section 7 concludes.

\section{The business environment in Lithuania in a comparative perspective}

In Lithuania, as in many other transition countries, private enterprise mushroomed during the initial transition period in the early 1990's. From 1993 - 1995 there was a steadily increasing trend in the number of enterprises in Lithuania in all size categories of registered businesses. However, the trend was reversed in the mid 1990's. ${ }^{2}$ In particular, the period from $1999-2000$ has seen a significant decrease in registered SMEs. At the beginning of 1999 there were 81,600 registered $^{3}$ SMEs but by the end of 2000 there were only 52,000 registered SMEs (SMEDA ${ }^{4}$

\footnotetext{
${ }^{1}$ See sections 3 and 4 below. Amadeus Database has been a popular source of firm level data, with the smallest firms truncated; a recent paper utilizing it for employment growth estimations is Faggio and Konings (2003). WBES World Bank survey and EBRD surveys are better in this respect, albeit the samples are still skewed; see: Beck et al. (2002), Batra et al. (2003), Fries et al. (2003). All those authors notice the problem.

2 We focus our study here on legally registered private enterprises though in doing so, we are probably underestimating the true size of Lithuania's private sector. A study 'Preliminary Estimation of Monetary flows in Lithuania' carried out by the Economic Research Center of Lithuania estimates that the 'underground' or informal economy could account for as much as 36 percent of GDP in 1994 and 41 percent of GDP in 1995 (World Bank 1998). A study carried out by the Lithuanian Department of Statistics presents more conservative estimates; accordingly, in 1995 the informal economy accounted for 23.4 percent of GDP (Lithuanian Department of Statistics 1997). However, the distortion is likely to more greatly affect the size and profitability of reported businesses then their actual number. That results from the fact, that the preferred strategy of informal activity may be to register a business but hide part of earnings and employment. (As argued by Kontorovich (1999) in relation to Russia).

${ }^{3}$ The number of registered SMEs is likely to include a significant percentage of inactive SMEs, thus a change in the register is only a crude indicator of the number of SMEs, which are active. Estimating the total number of active SMEs in Lithuania is difficult. For further discussion see Aidis 2003: 69)

${ }^{4}$ Lithuanian Development Agency for Small and Medium-sized Enterprises.
} 
2004). The main factors influencing this rapid decrease seem to be both internal changes and external economic shocks. Internal changes included increased labour costs (for hiring employees), additional taxation, additional bureaucratic barriers, increased competition from large chain stores (especially for trade related businesses) and low consumer demand. The latter factor may be linked to external shocks, which included both the Russian rouble crisis (August 1998) and an increasingly unfavourable Litas-Euro exchange rate implied by the fixed exchange regime combined with comparative nominal trends in Lithuania and the Euro area at that time ${ }^{5}$. The Lithuanian Human Development Report (UNDP 1999) noted that the Russian crisis was hardest on small businesses that were involved in trade with Russia. In addition, a simplification of the regulations for de-registering inactive businesses in 2000 resulted in the deregistration of many inactive businesses which may have influenced the apparently large decline in private businesses from 1999 to 2000.

\subsection{Obstacles to doing business}

Data collected jointly by the EBRD and World Bank in 1999 and 2002 rating obstacles to doing business in 26 transition countries highlights a number of key problems as perceived by business owners. The two survey results are presented in Table 1 below, for a relatively coherent group of eight new EU member states and three likely future members ${ }^{6}$.

Central and Eastern European (CEE) countries show visible improvements achieved in most areas, especially for infrastructure. However, regulation remains an exception, with very little progress on average. For the Lithuanian case, business owners seem to be more greatly affected by financial barriers than most other transition countries. Tax issues also score high as business barriers for the Lithuanian business owners, however this is consistent with the results for other transition economies. In fact, the Lithuanian scores are slightly below the mean in this respect. While on average the business owners in CEE find taxes the most difficult area, the opposite is true for infrastructure. One may also note that corruption is a dimension where the standard deviation across this group of countries remains particularly high in both 1999 and 2002. On corruption, Lithuania improved its relative scores between 1999 and 2002, going down from marginally above the cross-country average to being marginally below in the latter year.

\footnotetext{
${ }^{5}$ Since February 2, 2002, the Litas has been tied to the Euro.

${ }^{6}$ In addition to Bulgaria and Romania, we include Croatia, which did not yet start the EU membership negotiations, but is likely to in the near future.
} 
Table 1: Average rating of obstacles to doing business in 1999 and 2002:

New EU member states plus three likely future members.

\begin{tabular}{|c|c|c|c|c|c|c|c|c|c|c|c|c|c|c|}
\hline \multirow[b]{2}{*}{ year } & \multicolumn{2}{|c|}{ Financial } & \multicolumn{2}{|c|}{$\begin{array}{l}\text { Infra- } \\
\text { structure }\end{array}$} & \multicolumn{2}{|c|}{$\begin{array}{l}\text { Tax } \\
\text { issues }\end{array}$} & \multicolumn{2}{|c|}{$\begin{array}{l}\text { Regula- } \\
\text { tion }\end{array}$} & \multicolumn{2}{|c|}{ Judicial } & \multicolumn{2}{|c|}{ Crime } & \multicolumn{2}{|c|}{$\begin{array}{l}\text { Corruptio } \\
n\end{array}$} \\
\hline & '99 & ‘02 & '99 & ‘02 & '99 & '02 & '99 & ‘02 & '99 & ‘02 & '99 & '02 & '99 & '02 \\
\hline Bulgaria & 2.9 & 2.9 & 2.3 & 1.2 & 3.0 & 2.4 & 2.2 & 1.7 & 2.3 & 2.0 & 2.7 & 2.1 & 3.1 & 2.2 \\
\hline Croatia & 3.1 & 2.5 & 1.9 & 0.9 & 3.3 & 2.2 & 1.4 & 1.7 & 2.5 & 2.4 & 2.1 & 1.5 & 2.8 & 2.0 \\
\hline Czech R. & 2.4 & 2.5 & 2.5 & 1.0 & 3.3 & 2.4 & 1.8 & 1.7 & 2.2 & 1.7 & 1.9 & 1.7 & 2.2 & 1.6 \\
\hline Estonia & 2.4 & 2.1 & 1.6 & 1.4 & 2.7 & 2.0 & 1.1 & 1.8 & 1.8 & 1.7 & 1.6 & 1.7 & 1.7 & 1.6 \\
\hline Hungary & 3.0 & 2.4 & 1.6 & 0.9 & 3.1 & 2.4 & 2.4 & 1.6 & 2.0 & 1.3 & 2.1 & 1.3 & 2.5 & 1.6 \\
\hline Latvia & 2.6 & 2.0 & 2.1 & 1.7 & 3.2 & 3.0 & 1.8 & 2.1 & 2.4 & 2.0 & 2.1 & 1.8 & 2.6 & 2.2 \\
\hline Lithuania & 2.5 & 1.9 & 1.8 & 1.6 & 3.3 & 2.8 & 1.6 & 1.7 & 2.3 & 2.3 & 2.2 & 1.9 & 2.3 & 2.1 \\
\hline Poland & 3.0 & 3.0 & 1.7 & 0.7 & 3.2 & 2.9 & 2.3 & 2.0 & 2.4 & 1.9 & 2.5 & 1.9 & 2.7 & 1.9 \\
\hline Romania & 3.0 & 2.7 & 2.5 & 1.6 & 3.3 & 3.0 & 1.4 & 2.0 & 2.3 & 2.5 & 2.0 & 1.9 & 2.2 & 2.7 \\
\hline Slovak R. & 3.3 & 2.6 & 1.9 & 1.0 & 2.9 & 2.3 & 1.9 & 1.9 & 2.2 & 2.2 & 2.5 & 1.8 & 2.8 & 2.1 \\
\hline Slovenia & 2.9 & 2.1 & 1.8 & 0.7 & 2.9 & 1.7 & 2.2 & 1.4 & 2.4 & 1.6 & 1.8 & 1.1 & 2.2 & 1.3 \\
\hline Mean & 2.8 & 2.4 & 2.0 & 1.2 & 3.1 & 2.5 & 1.8 & 1.8 & 2.3 & 2.0 & 2.1 & 1.7 & 2.5 & 1.9 \\
\hline St.dev. & 0.3 & 0.4 & 0.3 & 0.4 & 0.2 & 0.4 & 0.4 & 0.2 & 0.2 & 0.4 & 0.3 & 0.3 & 0.4 & 0.4 \\
\hline $\begin{array}{l}\text { Mean‘02- } \\
\text { Mean‘99 }\end{array}$ & & -0.4 & & -0.8 & & -0.6 & & 0.0 & & -0.3 & & -0.4 & & -0.5 \\
\hline $\begin{array}{l}\text { Lith.indic. } \\
\text { - mean }\end{array}$ & 0.3 & 0.5 & 0.2 & -0.4 & -0.2 & -0.3 & 0.2 & 0.1 & 0.0 & -0.3 & -0.1 & -0.2 & 0.2 & -0.2 \\
\hline
\end{tabular}

Source: Adapted from Pissarides (2004) based on EBRD data with additional computations in the last four rows.

\section{Literature on determinants of SME growth}

We now turn to a brief literature review. First we argue that the growth of businesses and employment growth in particular are key performance indicators for SMEs. Next, we discuss findings on the determinants of growth.

\subsection{Business performance measures}

Even though no consensus regarding the definition of small business performance exists, venture profitability and increase in employees are two ways in which business performance is typically measured (Chandler and Hanks 1993; Robinson 1999; Vesper 1996; Watkins et al. 2003). However, the profitability indicator is problematic in the context of SMEs for two reasons. Firstly, SMEs frequently rely on simplified accounting where the measures of profit are not clear-cut. Secondly, it is typical for many new firms to follow a period of losses or low profitability in the initial phase of their existence. Thus, growth and growth expectations may be a better measure of performance. As argued by Johnson et al. (2000): 'Employment growth is perhaps the most important measure of performance from a welfare perspective. A private sector is successful in a post-communist country only to the extent it manages to create jobs'. (p. 13). Similar conclusions are supported by other authors. For instance Klapper et al. (2002) 
stress that the SME sector is the most dynamic part of transition economies. One may also note, that the importance of employment creation by the SME sector is also crucial in high income economies, as documented by Lopez-Garcia (2002) who confirm the role of SMEs as absorbing employment released from both industry and agriculture, by creating jobs in the service sector. And finally, while we focus on employment, the issue of growth can also be captured by the investment dimension, as in Fries et al. (2003).

Growth can be either measured by backward looking accounting and employment data or by forward looking expectations of owners. As the data is typically generated by surveys, there is a serious risk of substantial measurement error if data for several past years is collected. Moreover, in case of new recent start-ups there is not much past history to rely on, which leads to the sample selection bias. In addition, some studies have indicated that perceptions of performance may be more insightful indicators than objective measures because perceptions draws on the insider knowledge (Osborn et al. 1980; Watson et al. 2003) of firm's goals, strategy, structure and processes. Though it is not without controversy, there is increasing evidence indicating that attitudes such as intentions to grow a business can be used to predict behaviour (Davidsson 1991; Wiklund et al. 2003). ${ }^{7}$

\subsection{Determinants of growth}

The results of a number of studies indicated that both business and business owner characteristics can influence business growth. Existing studies have shown that human capital as measured by work experience, education and other skills that increase knowledge accumulation are not only important characteristics of entrepreneurial capacity (Sexton and Upton 1985) but have a positive influence on both firm survival, growth (Cooper et al. 1994) and entrepreneurial performance (Cooper and Gimeno-Gascon 1992; Chandler and Hanks 1998). Education seems to provide the knowledge base and analytical and problem-solving skills to more effectively deal with the demands of entrepreneurship (Watson et al. 2003). In a study of the influence of venture teams on venture performance, Watkins et al. (2003) find a significant and positive relationship between perceived venture growth and higher levels of education and work experience. They also found that younger business owners with fewer employees were significantly more likely to grow their ventures than the sample as a whole. However other

\footnotetext{
${ }^{7}$ Recent work by Wiklund et al. (2003) indicate that small business manager's feelings about whether the growth of their businesses is good or bad can be explained based on the consequences that they expect from growth. Interestingly, financial gain is not the outstanding determinant of attitude toward growth. Employee well-being is the single most important determinant of overall attitude toward growth. But it is not unlikely that the managers also have their own well-being in mind.
} 
studies have indicated that middle aged entrepreneurs are more likely to grow their businesses than other age groups (Burns 2001). Business sector may have an influence on these results with younger entrepreneurs growing their firms faster in IT sectors (Burns 2001). As a result, the relationship between business owner's age and business growth is still not completely understood.

Work experience can further supplement an entrepreneur's education with more practically based skills for venture performance. However perhaps even more importantly, previous entrepreneurial experience i.e. in having started up another private business may increase the likelihood for growth in the current business. This is a result of 'learning by doing' in which the entrepreneur improves their skills and chances for business success by building up their entrepreneurial experience. The different roles, which are played by the technically related work experience and by the entrepreneurial experience, may be linked to the recent empirical work based on the distinction between the two alternative views of entrepreneurship (Lazear 2004). Namely, the first view is based on believe 'that entrepreneurs are technical specialist who base their new companies on innovation' (Ibid., p. 208). If the view is correct, both previous sector-relevant job experience and specialist education may be critical factors determining entrepreneurial success. An alternative view however is that entrepreneurs are 'generalist', 'jacks of all trade', as their main role is in co-ordinating a range of activities, about which they need some sufficient amount of knowledge. In our interpretation and application of Lazear's (2004) results, previous entrepreneurial experience and more broad type of education may be more conductive to entrepreneurial success.

On a related theme, in a review of literature on the antecedents to business start-up and growth, Storey (1994) found reasonable evidence indicating a negative relationship between being unemployed before starting a business and subsequent business growth. Though unemployed individuals experience a strong push into self-employment, they may not have the skills needed to grow the business and may have lower growth aspirations.

Studies in Western countries have indicated that gender affects business development. More specifically, female businesses tend to be smaller and are less likely to grow than maleowned businesses (Cooper et al. 1994). A study by Cliff (1998) indicates that female business owners tend to have lower growth thresholds for their businesses than men, which can partially explain the tendency for women to have smaller businesses with lower turnovers. However, the same may not necessary hold for the transition economies such as Lithuania, where equal aspirations of women and high female entrepreneurship rates have been the norm (Aidis 2003). 
A study by Faggio and Konings (2003) on five transition countries shows a negative relationship between firm size and firm growth indicating that smaller firms are likely to grow faster than larger firms. However, as stressed by the authors, the small firms are heavily underrepresented in their sample. Similarly, Becchetti and Trovato (2002) found a negative link between size and growth (and positive with age of business), controlling for a wide range of factors, albeit again their sample contains firms with more then ten employees only. On the other hand, the results reported by Fries et al. (2003), based on a large cross-country sample from transition economies including micro firms, indicate a positive, albeit non-linear relationship between growth (as measured by both revenues and assets) and size in the relevant range of size. ${ }^{8}$ Similar findings are reported by Batra et al. (2003), using the WBES survey. Batra et al. show that while the difference between medium and small size companies in growth rate is not significant, it is becoming significant in relation to large firms, which grow faster.

Another important determinant of growth relates to the international versus domestic orientation of sales. As confirmed by Beck et al. (2002), utilizing a large cross-country survey, for which 80 percent of firms are small and medium sized, exporting is a highly significant factor affecting firm growth. Similar results based on the same sample are reported by Batra et al. (2003). In addition, Becchetti and Trovato (2002), found a positive, albeit marginally insignificant effect of exporting on growth for their sample of Italian firms.

Three studies, which focus directly on the link between business barriers and growth, are Johnson et al. (2000), Beck et al. (2002) and Batra et al. (2003). The latter two are both based on the WBES conducted by World Bank in 80 countries between mid 1998 and 2000. The econometric findings of the studies vary, and they are not fully compatible, as the survey instruments are different and the size distribution of firms in the samples differ. The first study (Johnson et al. 2000) does not cover firms with less than ten employees. Perception of barriers is captured by assessment of the extent of 'extralegal payments' in the business sector in which the company operates, and by assessment of the credibility of courts in enforcing contracts. On both measures, no significant effects on firm growth was found (Johnson et al. 2000).

On the other hand, Beck et al. (2002) relies on a more extensive range of indicators, and a larger sample with wide cross-country variation. They consider three dimensions: quality of financing, quality of the legal system, and corruption, all three based on 7-11 detailed questions with answers based on 6 point Likert scale. If a single dimension is included in the specification separately, all three turn out to have highly significant negative effect on firm growth. The effect

\footnotetext{
${ }^{8}$ As can be calculated from Table D.2 in their paper, the earliest point where the relationship between size and growth turns from positive to negative is somewhere above 900 employees (as measured by real growth in fixed
} 
of corruption becomes insignificant, when the three are included jointly, possibly due to multicollinearity. Another interesting finding is that the significance of these factors vary with the size of company: 'small firms report the highest financing and corruption constraints, whereas large firms report the highest legal constraints' (Beck et al. 2002, pp. 13-14). Similarly, using the same sample but different specifications, Batra et al. (2003) find that financing, high taxes and corruption are significantly and negatively associated with business sales growth.

In a related study in Lithuania, Aidis (2004) found that they do not influence the business in isolation but have an inter-related effect. For instance, business owners who perceived to be affected by formal barriers such as the tax level and business legislation was found to be more likely affected by informal barriers such as governmental corruption at the national level and the implementation of business regulations ${ }^{9}$. In our study, we are interested if the main business barriers identified by SME owners, namely taxes and corruption would have an interrelated effect on growth aspirations.

Figure 1 summarises the determinants of SME growth as found in the literature and according to our predictions. The relevant factors are grouped as owner attributes, firm level attributes and business environment characteristics.

Figure 1: Influences on Business Growth

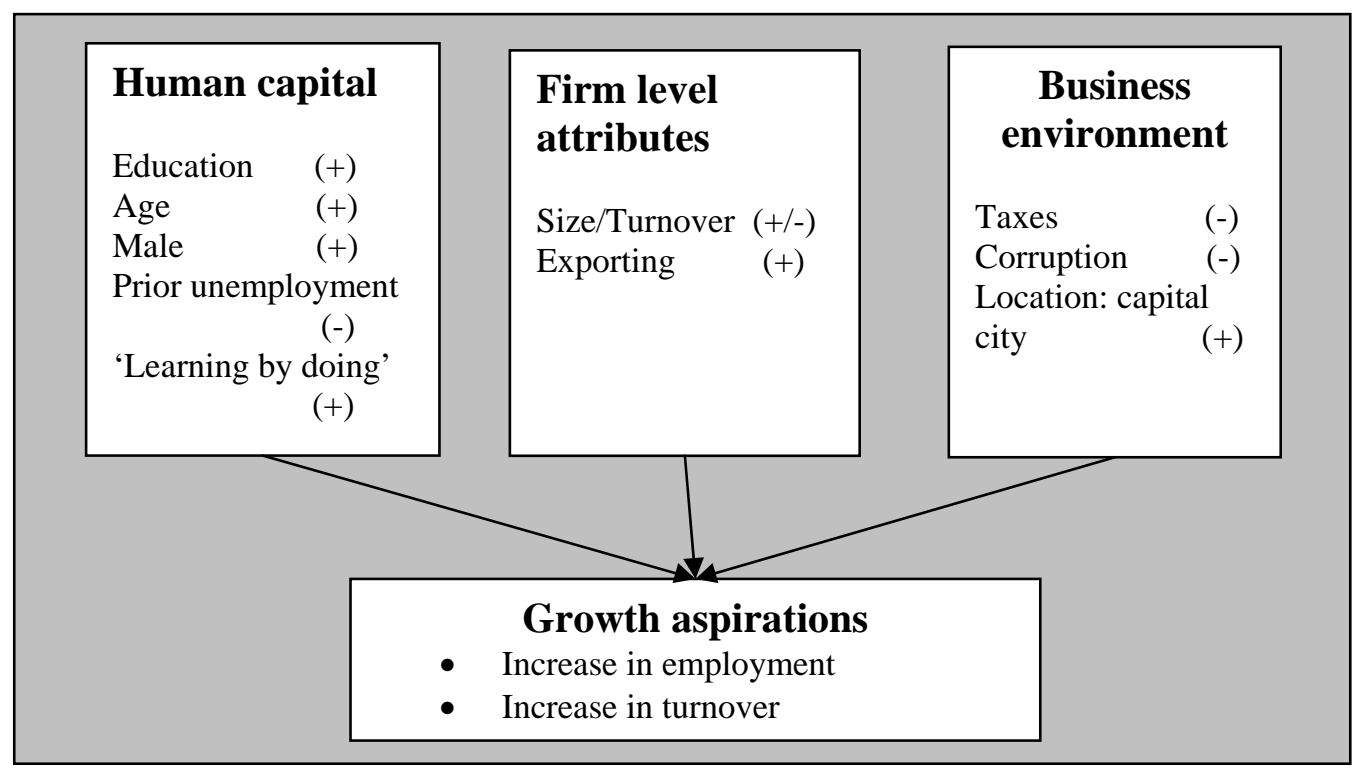

assets; see Fries et al. 2003, p.46). 


\section{Survey and sample characteristics ${ }^{10}$}

Our analysis is based on data collected by one of the authors in Lithuania. From September - December 2000, Lithuanian language questionnaires were sent out to private business owners throughout Lithuania. Due to the inability to obtain accurate lists of operating private businesses in Lithuania ${ }^{11}$, the survey was not based on a random sample and most addresses were obtained through the membership lists of various entrepreneurship organizations $^{12}$ This may have resulted in a bias for businesses that are older and have higher turnovers than the average private business in Lithuania. The response rate was high, at fifty percent. Of the 505 respondents, 399 were business owners ${ }^{13}$.

Table 2 compares distribution of firms in our sample with that reported by the Lithuanian Department of Statistics (LDS). While the smallest companies are still underrepresented in our sample, we may note the bias is still smaller than in many other studies, where it is not unusual to exclude all firms below ten employees or similar size.

Table 2: Enterprise type as percentage of total private enterprises in Lithuania

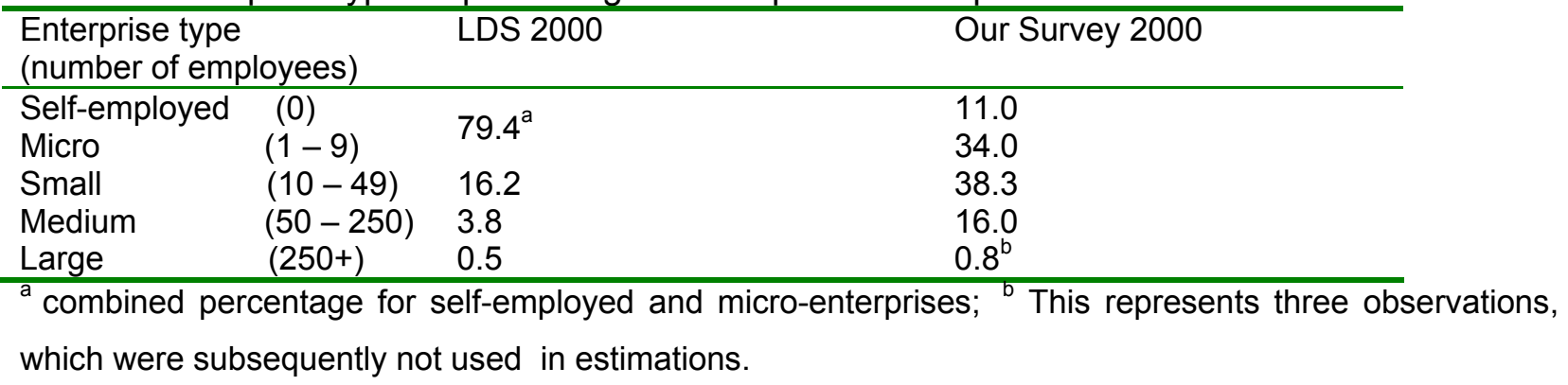

\footnotetext{
${ }^{9}$ Due to space constraints, we refer interested reader to Aidis (2004) for further discussion of business barriers in Lithuania.

${ }^{10}$ An extensive description of the survey and sample characteristics can be found in Aidis (2003).

${ }^{11}$ As in many other transition countries, an accurate list of legal enterprises in Lithuania does not exist. Previous surveys attempted using the official list of registered businesses from the Lithuanian Department of Statistics indicated that the official register was rife with non-existent businesses or inaccurate addresses. See Aidis (2003) for further discussion.

${ }^{12}$ The address lists of members from the five branches of the 'private' Lithuanian Chambers of Commerce (Vilnius, Kaunas, Panevezys, Siauliai, and Klaipeda), the Lithuanian Business Employer's Confederation (LVDK) and the Kaunas Regional Association of SMEs were used. The Lithuanian Chamber of Commerce and the LVDK are two of the largest entrepreneurship organizations in Lithuania.

${ }^{13}$ A business owner met the following criteria: they had their own business, it was still in operation and their main business activities were not in the agriculture sector.
} 


\subsection{Growth}

Our analysis of growth intentions is based on responses to the following question from the survey:

In the next five years, do you think that your business will:

(please mark all relevant responses):

(a) increase the number of employees

(b) increase turnover

(c) decrease the number of employees

(d) decrease turnover

(e) stay the same

(f) I don't know

The question is asked in a depersonalised, objective mode, i.e. about expectations, not intentions or strategies of the owner, to avoid possible bias. The respondents would typically assume that growth is something positive and might be inclined to present themselves in a better light, if asked about their intentions and potential. The wording applied here suggests that it is not only the entrepreneur, who is responsible for the enterprise development.

The analysis was greatly facilitated by the fact that all respondents who declared expected increase in employment, also declared expected increase in turnover, but not vice versa. These results lead to the following ranking, presented in Table 3.

Table 3: Categorization of answers for the question on growth expectations

\begin{tabular}{|c|c|c|c|}
\hline $\begin{array}{l}\text { a. variable 'future' } \\
\text { (four categories) }\end{array}$ & $\begin{array}{l}\text { frequency of } \\
\text { answers: }\end{array}$ & $\begin{array}{l}\text { b. variable 'future_3c' } \\
\text { (three categories) }\end{array}$ & $\begin{array}{l}\text { frequency of } \\
\text { answers: }\end{array}$ \\
\hline $\begin{array}{l}\text { (4) increase employment and } \\
\text { turnover }\end{array}$ & 182 & & \\
\hline $\begin{array}{l}\text { (3) increase turnover, but not } \\
\text { employment }\end{array}$ & 83 & $\begin{array}{l}\text { (3) increase employment and } \\
\text { turnover }\end{array}$ & 182 \\
\hline (2) the same or don't know & 106 & $\begin{array}{l}\text { (2) increase turnover, but not } \\
\text { employment }\end{array}$ & 83 \\
\hline $\begin{array}{l}\text { (1) decrease turnover or } \\
\text { employment }\end{array}$ & 22 & $\begin{array}{l}\text { (1) the same or don't know \& } \\
\text { decrease turnover or } \\
\text { employment }\end{array}$ & 128 \\
\hline (missing) & 6 & (missing) & 6 \\
\hline Total & 399 & Total & 399 \\
\hline
\end{tabular}

As the number of responses in the lowest category is relatively small, combining it with the one above may be reasonable, as illustrated by an alternative categorisation (b) above. We estimated alternative models, using both specifications (see below). In particular, we applied the ordinal probit estimator, where, for a sequence of cut points: $k_{0}, \ldots, k_{i}, \ldots, k_{n}$ (with $k_{0}$ corresponding to $-\infty$ and $k_{n}$ to $+\infty$ ), the probability of observing an outcome $i$ is given by: 


$$
P(\text { outcome }=i)=P\left(k_{i-1}<\boldsymbol{X} \boldsymbol{\gamma}+u<k_{i}\right)=\Phi\left(k_{i}-\boldsymbol{X} \boldsymbol{\gamma}\right)-\Phi\left(k_{i-1}-\boldsymbol{X} \boldsymbol{\gamma}\right)
$$

where $X_{Y}$ is a matrix of explanatory variables with a corresponding (column) vector of coefficients and $\Phi($.) refers to the standard normal cumulative distribution function.

In addition to this model, we also applied a simpler binary probit model, with the dependent variable distinguishing between the entrepreneurs predicting employment growth and all other outcomes:

$$
P(\text { outcome }=1)=\Phi(\boldsymbol{X} \boldsymbol{\gamma})=\int_{-\infty}^{X_{\gamma}} \phi(t) d t
$$

\section{Variables defined}

In deriving the set of explanatory variables, we draw from the literature discussed in section 3. Our particular interest is in the link between perceptions of business barriers and growth expectations. The difference in explanatory power of barriers may not correspond to their direct ranking. To give an example, demand and financial constraints, typical for hardbudget market economy are commonly perceived as a major nuisance, as confirmed by the survey results. Yet it does not imply these have the most impeding impact on growth. Assessment of the importance of given obstacles may indicate problems in everyday business, which the entrepreneurs may be able to overcome nevertheless. Quite a different set of factors may influence the decisions to develop and expand. 
The survey generated data on a number of characteristics that are consistent with our prior expectations on a possible set of determinants of growth. Firstly, we have size, as measured by employment. The variable distribution is highly skewed to the left, with 43 observations in self-employed category, i.e. with no employment other than the owner of the business (see Table 2). For that reason, we categorise the employment variable, using the four size categories, as recommended by the standard EU definition. The benchmark category is 'self employed' and we introduce dummy variables for micro, small and medium size enterprises correspondingly (see Table 2). Three observations with employment above 250 are eliminated from the analysis. Testing for the relationship between size and growth expectations is important, since as indicated in section 3, the link between the size and growth of enterprises remains a highly debated issue in the literature.

We are also interested in examining if human capital variables such as sector-relevant job experience, entrepreneurial experience, starting from employment or non-employment, education, age and gender are related to growth intentions. In particular, the first two may be perceived as proxies for the distinction between 'specialist' and 'generalist' human capital, as defined by Lazear (2004). We include these as well as firm level variables such as export orientation, location and sectoral affiliation in our estimations. Export orientation provides us with an indication of the influence of internationalized business operations on business growth. Capital city location is included in order to control for the effects of rapid economic growth concentrated in the capital city as compared to the rest of the country. This specific capital city development vs. underdeveloped smaller cities characterizes many transition countries. Finally controlling for sector effects is a standard for these types of estimations.

The questionnaire instrument related to perception of barriers had two parts. In the first part, the respondents were asked to assess the importance of nineteen business barriers, each separately. In the second part, the task was to identify the three most important barriers. The problem with the separate assessment of barriers is that it is based on 5 point Likert scale and the respondent is unable to differentiate between the most serious barriers, which are all given the highest scores. In this respect, the second question (enumerating the three most important barriers) has an advantage and this is the one we used for the subsequent analysis.

For all of the barriers included in the questionnaire, Figure 2 below illustrates the frequency of responses identifying a given barrier as one of the three most important ones. 
Figure 2:Percentage of entrepreneurs identifying a given dimension as one of the three most important business barriers.

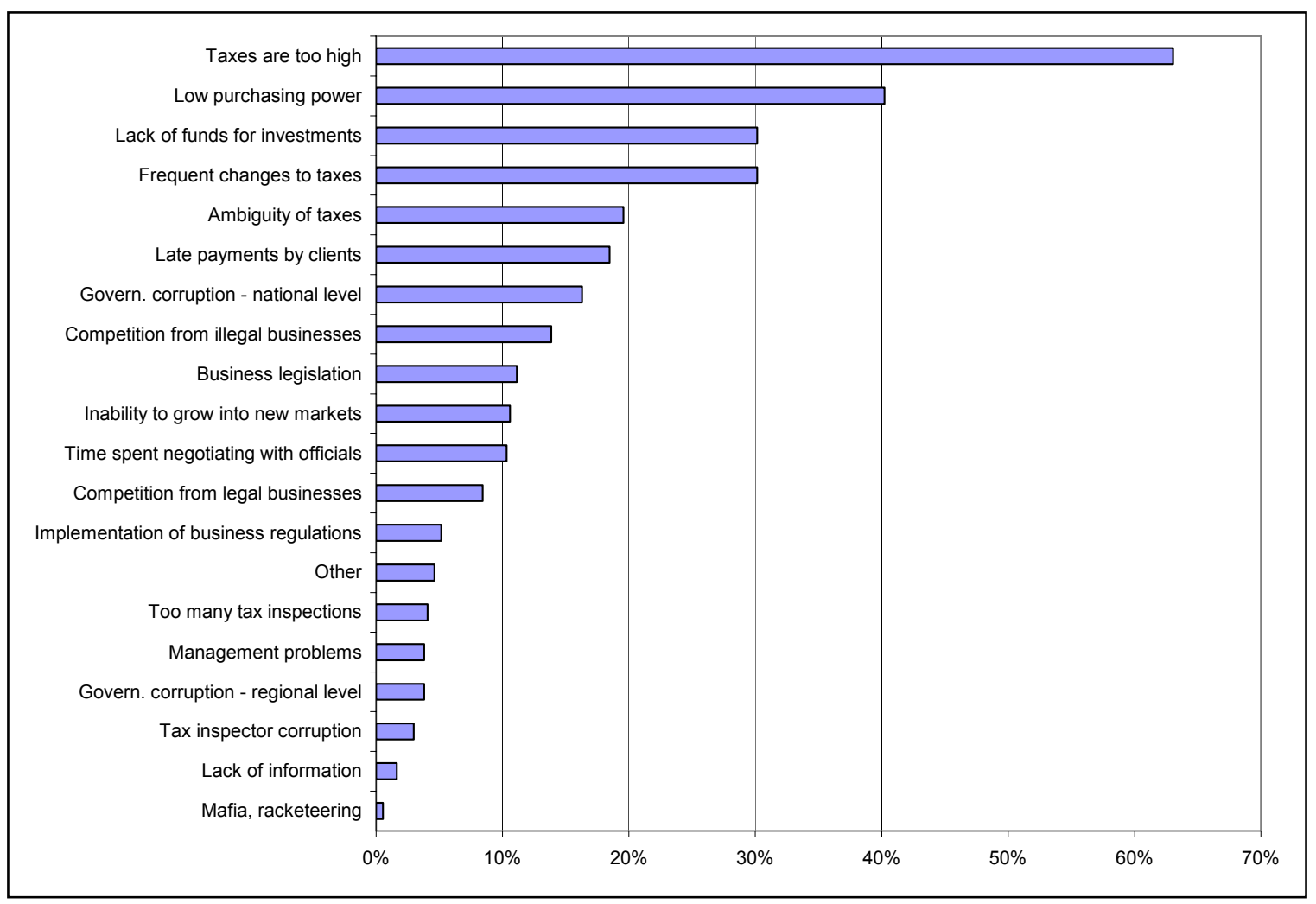

Our estimation strategy was to include dummy variables for seven barriers, which were most frequently identified. It turned out that only those related to taxes and corruption were significant. In addition, there is multicollinearity between the tax dimensions, which makes the coefficients sensitive to small changes in specification and data, i.e. not robust and problematic to rely on. There is no single straightforward solution to this problem. Our response was to restrict ourselves to the two of the most important business barriers, namely 'taxes to high' and 'corruption at the national level' and exclude 'frequent changes to tax policies' and 'ambiguity of taxes'. However, interpreting the results, one should bear in mind that the retained tax indicator should not be narrowly related to the level of taxes, but interpreted as a proxy for a broader cluster of problems with tax system.

The results of six specifications are reported below. Our dependent variable relates to expected growth categorised into four ranks, as described above, where the highest rank is the expected positive growth of both employment and turnover. In the first specification, we use the dependent variable with four categories and include indicators for human capital, exporting, 
location, employment size categories, sectoral controls and perceptions of barriers, as described above. In the second specification, we drop insignificant factors. In the specification two, we use three categories of expected growth (instead of four) as dependent variable and in specification three we compress the dimensions further, by using expected employment growth as a binary variable, to see if the results are robust to the modification. Finally, specifications four to six, replicates the three previous ones with size measure given by turnover, instead of employment. See Appendix 1 for a summary of the independent and dependent variables used in our estimation model.

\section{Results}

All the estimation results are presented in Tables $4 \mathrm{a}$ and $4 \mathrm{~b}$. Unemployed prior to starting a business, age and gender are not significant as predictors of growth expectations. Age is highly insignificant, while gender is marginally significant in one specification, and insignificant in others. Interestingly, the sign of the gender coefficient is positive is all specifications, indicating that the impact of gender may be very different from that observed in high income countries; if anything women entrepreneurs have higher growth aspirations than their male counterparts. Unemployment prior to starting a business also has the expected negative sign. The other human capital measures are either significant or marginally insignificant depending on the specification. In particular, we found no evidence that the 'specialist' experience is more relevant than 'generalist' or vice versa. Both seem to matter, as documented by coefficients on experience in the same sector of activity and on entrepreneurial experience. Though 'learning by doing' through previous job experience and entrepreneurial experience does have a positive effect. In addition, we found a clear general positive effect of higher education. On the firm level, we can see a clear positive effect of exporting, and positive, albeit insignificant effect of business being located in the capital city. Sectoral affiliation is mostly insignificant, apart from some negative effect on growth expectations of 'services activities other than trade'.

Size effects are clearly important. Medium, small and micro size companies expect to grow, while the self-employed express little interest in developing their business. Moreover, the coefficients in Table 8 a are neatly ordered according to size group: the larger the size category, the more likely is that the company will grow.

Here, our results are consistent with those obtained from research based on samples, which include the smallest firms, as in Fries et al. (2003). It may also be interpreted as providing support for the arguments presented by Earle and Sakova (2001) theorizing that in transition 
countries, own account workers (business without employees) a more likely a form of hidden unemployment than a form of entrepreneurship. This is clearly a point of concern for policy makers.

When we replace employment by turnover as a size measure, the most robust result is that the entrepreneurs that express an interest to grow are those whose annual turnover is about 300,000 Euro or more (two highest categories in terms of revenue, between which there is little difference in coefficients in all specifications). Thus, the big are getting bigger, and micro enterprises and self-employed are stagnant.

Taxes and corruption have a negative effect on growth aspirations throughout. The result is consistent with the literature discussed above. In the case of corruption it also indicates that this barrier, while not named as very important by the majority of entrepreneurs (see Figure 3), has a detrimental effect on growth where encountered. 
Table 8a:Results

\begin{tabular}{|c|c|c|c|}
\hline & (1) & (2) & (3) \\
\hline & $\begin{array}{l}\text { growth expectations } \\
\text { (ordered using four } \\
\text { ranks) }\end{array}$ & $\begin{array}{ll}\text { growth expectations } \\
\text { (ordered } & \text { using } \\
\text { three ranks) } & \end{array}$ & $\begin{array}{l}\text { growth expectations } \\
\text { (positive } \\
\text { employment growth } \\
\text { as binary outcome) }\end{array}$ \\
\hline \multicolumn{4}{|l|}{ Human capital: } \\
\hline higher education & $0.37^{*}(0.15)$ & $0.34^{*}(0.16)$ & $0.26(0.18)$ \\
\hline job experience same sector & $0.20(0.13)$ & $0.25 \dagger(0.14)$ & $0.26+(0.15)$ \\
\hline entrepreneurial experience & $0.27^{*}(0.13)$ & $0.32^{*}(0.14)$ & $0.18(0.15)$ \\
\hline Unemployed prior to starting & $-0.24(0.25)$ & $-0.15(0.27)$ & $-0.26(0.30)$ \\
\hline business owner's age & $-0.08(0.06)$ & $-0.09(0.07)$ & $-0.09(0.07)$ \\
\hline age2 & $0.0008(0.0007)$ & $0.0010(0.0007)$ & $-0.0010(0.0008)$ \\
\hline female & $0.16(0.15)$ & $0.23(0.16)$ & $0.18(0.18)$ \\
\hline \multicolumn{4}{|l|}{ Firm level attributes: } \\
\hline company is exporting & $0.34^{*}(0.14)$ & $0.31^{*}(0.14)$ & $0.22(0.16)$ \\
\hline location: Vilnius & $0.14(0.15)$ & $0.16(0.15)$ & $0.04(0.17)$ \\
\hline \multicolumn{4}{|c|}{ Firm size: number of employees ( reference category: self employed) } \\
\hline micro & $0.49 *(0.23)$ & $0.68^{* *}(0.25)$ & $0.56^{*}(0.28)$ \\
\hline small & $0.57^{*}(0.23)$ & $0.82^{* * *}(0.25)$ & $0.82^{* *}(0.28)$ \\
\hline medium & $0.80^{* *}(0.28)$ & $1.05^{* \star *}(0.299)$ & $1.00^{* *}(0.33)$ \\
\hline \multicolumn{4}{|l|}{ Barriers } \\
\hline taxes & $-0.31^{*}(0.14)$ & $-0.35^{*}(0.14)$ & $-0.35^{*}(0.16)$ \\
\hline corruption & $-0.41^{*}(0.17)$ & $-0.34 \dagger(0.18)$ & $-0.31(0.20)$ \\
\hline \multicolumn{4}{|c|}{ Sectors (reference category: manufacturing) } \\
\hline construction & $0.02(0.35)$ & $0.05(0.36)$ & $0.16(0.38)$ \\
\hline retail trade & $0.04(0.18)$ & $0.11(0.19)$ & $0.15(0.21)$ \\
\hline wholesale trade & $-0.05(0.21)$ & $-0.03(0.22)$ & $0.11(0.23)$ \\
\hline business services & $-0.25(0.22)$ & $-0.21(0.23)$ & $-0.23(0.25)$ \\
\hline other services & $-0.37 \dagger(0.21)$ & $-0.52(0.22)$ & $-0.30(0.25)$ \\
\hline Log likelihood & -382 & -325 & -213 \\
\hline $\operatorname{LR} x^{2}$ & $55^{* * *}$ & $62^{\star * *}$ & $40^{* *}$ \\
\hline Pseudo $\mathrm{R}^{2}$ & 0.07 & 0.09 & 0.09 \\
\hline No of observations & 338 & 338 & 339 \\
\hline
\end{tabular}

Notes

(i) estimator: ordered probit for specifications 1- 2; binary probit for specification 3,

(ii) three companies with employment above 250 excluded from estimation,

(iii) standard errors in parentheses,

(iv) significant at: $\dagger 0.10{ }^{*} 0.05^{* *} 0.01{ }^{* * *} 0.001$,

(v) ancillary parameters (and constant in specification 3 ) not reported, and available on request. 
Table 8b: Results

\begin{tabular}{|c|c|c|c|}
\hline & (4) & (5) & (6) \\
\hline & $\begin{array}{l}\text { growth expectations } \\
\text { (ordered using four } \\
\text { ranks) }\end{array}$ & $\begin{array}{ll} & \text { growth expectations } \\
\text { (ordered } & \text { using } \\
\text { three ranks) } & \end{array}$ & $\begin{array}{l}\text { growth expectations } \\
\text { (positive } \\
\text { employment growth } \\
\text { as binary outcome) }\end{array}$ \\
\hline \multicolumn{4}{|l|}{ Human capital: } \\
\hline higher education & $0.33(0.15)$ & $0.30(0.16)$ & $0.26(0.17)$ \\
\hline job experience in same sector & $0.22(0.13)$ & $0.25 \dagger(0.14)$ & $0.25 \dagger(0.15)$ \\
\hline entrepreneurial experience & $0.21(0.13)$ & $0.26 \dagger(0.14)$ & $0.13(0.15)$ \\
\hline unemployment prior to starting & $-0.17(0.25)$ & $-0.05(0.27)$ & $-0.19(0.30)$ \\
\hline business owner's age & $-0.07(0.06)$ & $-0.07(0.07)$ & $-0.08(0.07)$ \\
\hline age2 & $0.0007(0.0007)$ & $0.0007(0.0007)$ & $0.0008(0.0008)$ \\
\hline female & $0.24(0.16)$ & $0.31 \dagger(0.17)$ & $0.26(0.19)$ \\
\hline \multicolumn{4}{|l|}{ Firm level attributes: } \\
\hline company is exporting & $0.34^{*}(0.14)$ & $0.25 \dagger(0.14)$ & $0.25(0.16)$ \\
\hline location: Vilnius & $0.10(0.15)$ & $0.13(0.16)$ & $0.03(0.17)$ \\
\hline \multicolumn{4}{|c|}{ Firm size: Annual turnover ( reference category: below 100,000 Lt ( $\approx$ Euro 30,000)) } \\
\hline $100,001-500,000 \mathrm{Lt}$ & $0.52^{*}(0.21)$ & $0.51^{*}(0.23)$ & $0.41(0.25)$ \\
\hline $500,001-1,000,000 \mathrm{Lt}$ & $0.29(0.22)$ & $0.27(0.24)$ & $0.36(0.26)$ \\
\hline $1,000,001-5,000,000 \mathrm{Lt}$ & $0.64^{* * *}(0.20)$ & $0.65^{\star *}(0.22)$ & $0.60^{*}(0.24)$ \\
\hline$>5,000,000 \mathrm{Lt}$ & $0.63^{*}(0.25)$ & $0.69^{* *}(0.262)$ & $0.62 *(0.29)$ \\
\hline \multicolumn{4}{|l|}{ Barriers } \\
\hline taxes & $-0.27^{*}(0.14)$ & $-0.28(0.14)$ & $-0.29+(0.15)$ \\
\hline corruption & $-0.30 \dagger(0.17)$ & $-0.22(0.18)$ & $-0.18(0.20)$ \\
\hline \multicolumn{4}{|c|}{ Sectors ( reference category: manufacturing) } \\
\hline construction & $0.15(0.27)$ & $0.21(0.38)$ & $0.37(0.40)$ \\
\hline retail trade & $-0.04(0.18)$ & $0.00(0.19)$ & $0.06(0.21)$ \\
\hline wholesale trade & $-0.16(0.20)$ & $-0.16(0.21)$ & $-0.04(0.23)$ \\
\hline business services & $-0.26(0.21)$ & $-0.26(0.22)$ & $-0.33(0.25)$ \\
\hline other services & $-0.36 \dagger(0.21)$ & $-0.55^{*}(0.23)$ & $-0.29(0.15)$ \\
\hline Log likelihood & -369 & -318 & -210 \\
\hline $\operatorname{LR}^{2}$ & $58^{* * *}$ & $59^{* * *}$ & $36^{*}$ \\
\hline Pseudo $\mathrm{R}^{2}$ & 0.07 & 0.08 & 0.08 \\
\hline No of observations & 330 & 330 & 331 \\
\hline
\end{tabular}

Notes:

(i) estimator: ordered probit for specifications 4 and 5; binary probit for specification 6 ,

(ii) three companies with employment above 250 excluded from estimation

(iii) standard errors in parentheses,

(iv) significant at: $† 0.10{ }^{*} 0.05{ }^{* *} 0.01{ }^{* * *} 0.001$

(v) ancillary parameters for cut-off points available on request.

\section{Conclusions}

Our study focused on factors affecting the growth of new firms, which is arguably the key indicator of business performance and entrepreneurship as well as an important factor in overall economic development. Following recent trends in the literature, we use business owner expectations of future growth as a methodologically attractive way of measuring growth potential for SMEs. We experiment with alternative formulations of this measure and found the results robust. 
In particular, we discover that growth expectations differ according to firm size, with small and medium size enterprises expecting growth and micro firms and self-employed being more stagnant. Arguably, we are able to detect these effects, due to a broad coverage of size dimension by our sample. Analysis of the results in the available literature shows that the link between size and growth is sensitive to sample coverage.

We also analyse the link between the perceptions of barriers by business owners and their growth expectations. Both taxation and corruption were found to be significant barriers to the growth aspirations of SMEs in our sample.

An interesting but not surprising result was the significant influence of private business experience on intention to grow in the current business. This effect may be more important in the transition context than in advanced western countries since 'entrepreneurial' skills were never taught (directly or indirectly) in the centrally planned system. Our results seem to indicate that 'learning by doing' has proved to be an important form of human capital in the transition context.

Finally, we are able to confirm two further results, consistent with the literature. Firstly, export orientation is an important factor facilitating growth of small firms. Secondly, human capital matters: higher education of entrepreneurs is correlated with higher growth expectations.

Further research in this area would be useful in order to model the interactions between the characteristics of entrepreneurs, perceptions of barriers and growth expectations in more detail.

Our study also provides some insights for business growth in the transition country context. Though our data is from Lithuania, EBRD indicators show that Lithuania scores in an average way as compared to other transition countries in Central and Eastern Europe and in that respect can be seen as a typical transition country example. Our results indicate that even as formal institutions are established, informal practices such as corruption continue to form major obstacles to private business development and growth. The policy implications of these results support the development of strategies to reduce the possibility for corruption to occur so as through depersonalized contact with governmental officials. 


\section{References}

Aidis, R. 2003. By law and by custom: Factors affecting small- and medium-sized enterprises during the transition in Lithuania. Thela Thesis: Amsterdam.

Aidis, R. 2004. 'Institutional impediments to small- and medium-sized enterprise development in transition countries', Small Business Economics, forthcoming.

Batra, G., D. Kaufmann and A. Stone. 2003. Investment Climate Around the World: Voices of the Firms from the World Business Environment Survey. Washington DC: The World Bank.

Becchetti, L. and G. Trovato. 2002. 'The Determinants of Growth for Small and Medium

Sized Firms. The Role and Availability of External Finance'. Small Business Economics Vol. 19, 291-306.

Beck, T., A. Demirgüc-Kunt, and V. Maksimovic. 2002. 'Financial and Legal Constraints to Firm Growth. Does Size Matter?' World Bank, mimeo.

Bird, B. and M. Jelinek. 1988. 'The operation of entrepreneurial intentions' Entrepreneurship Theory and Practice, vol. 13: 2, pp. $21-29$.

Burns, P. 2001. Entrepreneurship and Small Business. London: Palgrave Macmillan.

Chandler, G. and S. Hanks.1993. Measuring the performance of emerging businesses: A validation study, Journal of Business Venturing vol. 8, pp. $391-408$.

Chandler, G. and S. Hanks. 1998. 'An examination of the substitutability of founders' human and financial capital in emerging business ventures', Journal of Business Venturing vol. 13, pp. $353-369$.

Cliff, J. 1998. 'Does one size fit all? Exploring the relationship between attitudes towards growth, gender and business size', Journal of Business Venturing, vol. 13:6, pp. 523 - 542.

Cooper, A. and F. Gimeno-Gascon. 1992. 'Entrepreneurs, processes of founding and new firm performance' in D. Sexton and J. Kasarda (eds) The state of the art of Entrepreneurship, PWS-Kent: Boston, MA, pp. 301 - 340.

Cooper, A. 1993. 'Challenges in predicting new firm performance'. Journal of Business Venturing 8: 241 - 253.

Cooper, A., J. Gimeno-Gascon and C.Y. Woo. 1994. 'Initial human and financial capital as predictors of new venture performance', Journal of Business Venturing, vol. 9:5, pp. 371395.

Davidsson, P. 1991. 'Continued Entrepreneurship: Ability, need and opportunity as determinants of small firm growth'. Journal of Business Venturing 6:405-429.

Earle, J. and Z. Sakova. 2000. 'Business start-ups or disguised unemployment? Evidence on the character of self-employment from transition economies'. Labour Economics 7:575 601.

European Bank for Reconstruction and Development (EBRD). 2002. Transition Report: Agriculture and rural transition. London.

European Bank for Reconstruction and Development (EBRD). 2003. Transition Report: Integration and Regional Cooperation. London.

Faggio, G. and J. Konings. 2003. 'Job creation, job destruction and employment growth in transition countries in the 90s', Economic Systems vol. 27, pp. 129 - 154.

Fries, S., T. Lysenko and S. Polanec 2003. 'The 2002 Business Environment and Enterprise Performance Survey: Results from a Survey of 6,100 Firms', EBRD Working Paper, No. 84. Herron, L. and R. Robinson. 1993. 'A structural model of the effects of entrepreneurial characteristics on venture performance'. Journal of Business Venturing 8:281 - 294. Johnson, S., J. McMillan and C. Woodruff. 2000., 'Entrepreneurs and the ordering of institutional reform. Poland, Slovakia, Romania, Russia and Ukraine compared', Economics 
of Transition, 8, pp. 1-36.

Klapper, L., V. Sarria-Allende and V. Sulla. 2002. 'Small and Medium-Size Enterprise Financing in Eastern Europe'. World Bank Research Policy Working Paper. No. 2933.

Kolvereid, L. 1992. 'Growth Aspirations among Norwegian entrepreneurs'. Journal of Business Venturing 7: 209 - 222.

Kontovorich, V. 1999. 'Has New Business Creation in Russia come to a halt?' Journal of Business Venturing 14: 451-60.

Lazear, E. 2004. 'Balanced Skills and Entrepreneurship' American Economic Review 94: 208-211.

Lithuanian Department of Statistics. 1997. Neapskaitoma Ekonomika: Sampratos, Tyrimai, Problemos. Vilnius.

Lithuanian Department of Statistics. 2001. Statistical Yearbook of Lithuania 2000. Vilnius.

Lithuanian Development Agency for Small and Medium-sized Enterprises. (SMEDA) 2004. Survey of Lithuanian SMEs, http://www.svv.lt.

Lopez-Garcia, P. 2002. Labour Market Performance and Start-Up Costs: OECE Evidence, Centre for Economic Performance Discussion Paper, No. 565.

Pissarides, F. 2004. 'Financial Structures and private sector development in the new Europe' Chapter 3 in D. Masciandoro (ed) Financial Intermediation in the New Europe: Banks, Markets and Regulation in the Accession Countries, Edward Elgar: Northhampton, MA, forthcoming

Robinson, K. 1999. 'An examination of the influence of industry structure on eight alternative measures of new venture performance for high potential independent new ventures', Journal of Business Venturing vol. 14, pp. 165 - 187.

Sexton, D. and N. Upton. 1985. 'The entrepreneur: A capable executive and more', Journal of Business Venturing vol. 1, pp. $129-140$.

Storey, D. 1994. Understanding the Small Business Sector. London: International Thomson Business Press.

Vesper, K. 1996. New Venture Experience, Vector Books: Seattle WA, pp. 1- 19.

Watson, W., W. Stewart, Jr. and A. BarNir. 2003. 'The effects of human capital, organizational demography and interpersonal processes on venture partner perceptions of firm profit and growth', Journal of Business Venturing vol. 18, pp. $145-164$.

Wiklund, J., Davidsson, P. and F. Delmar. 2003. 'What do they think and feel about growth? An expectancy-value approach to small business manager's attitudes toward growth', Entrepreneurship, Theory and Practice Spring 2003, pp. $247-270$.

World Bank. 1998. Lithuania: An Opportunity for Economic Success. Washington DC. United National Development Program (UNDP). 2000. Lithuanian Human Development Report. Vilnius, Lithuania. 
Appendix 1: Variables defined

\begin{tabular}{|c|c|c|c|c|}
\hline $\begin{array}{l}\text { Independent } \\
\text { Variables }\end{array}$ & Characteristic & $\mathbf{N}$ & Mean & SD \\
\hline \multicolumn{5}{|l|}{ Human capital } \\
\hline Higher education & $\begin{array}{l}\text { One if the respondent has a university education, zero } \\
\text { otherwise. }\end{array}$ & 393 & 0.72 & 0.45 \\
\hline $\begin{array}{l}\text { Job experience in } \\
\text { same sector }\end{array}$ & $\begin{array}{l}\text { One if the respondent has previous employment experience } \\
\text { in the sector where they started their own business, zero } \\
\text { otherwise. }\end{array}$ & 389 & 0.48 & 0.50 \\
\hline $\begin{array}{l}\text { Experience with other } \\
\text { business }\end{array}$ & $\begin{array}{l}\text { One if the respondent had started a private business } \\
\text { besides their current business, zero otherwise. }\end{array}$ & 395 & 0.02 & 0.14 \\
\hline $\begin{array}{l}\text { Unemployed prior to } \\
\text { starting }\end{array}$ & $\begin{array}{l}\text { One if the respondent had not been in employment prior to } \\
\text { starting their private business, zero otherwise. }\end{array}$ & 395 & 0.73 & 0.26 \\
\hline Business owner's age & Continuous variable measuring business owner age. & 390 & 42.76 & 8.77 \\
\hline Age2 & Age variable squared & 390 & 1905.2 & 787.9 \\
\hline $\begin{array}{l}\text { Female } \\
\text { Firm level attributes }\end{array}$ & One if the respondent is female, zero otherwise. & 396 & 0.25 & 0.43 \\
\hline
\end{tabular}




\begin{tabular}{|c|c|c|c|c|}
\hline Exporting & One if the business is exporting, zero otherwise. & 396 & 0.48 & 0.50 \\
\hline Location: Vilnius & One if the business is located in Vilnius, zero otherwise. & 394 & 0.26 & 0.44 \\
\hline Micro & $\begin{array}{l}\text { One if the business has less than } 9 \text { employees, zero } \\
\text { otherwise. }\end{array}$ & 396 & 0.34 & 0.48 \\
\hline Small & $\begin{array}{l}\text { One if the business has } 10 \text { to } 49 \text { employees, zero } \\
\text { otherwise. }\end{array}$ & 396 & 0.39 & 0.49 \\
\hline Medium & $\begin{array}{l}\text { One if the business has } 50 \text { to } 249 \text { employees, zero } \\
\text { otherwise. }\end{array}$ & 396 & 0.16 & 0.37 \\
\hline Construction & $\begin{array}{l}\text { One if the business is engaged in construction, zero } \\
\text { otherwise. }\end{array}$ & 396 & 0.04 & 0.19 \\
\hline Turnover & $\begin{array}{l}\text { Ordinal variable indicating annual business turnover for } \\
\text { 1999. Five categories: (1) up to } 100000 \mathrm{Lt} \text {; (2) } 100001- \\
500000 \mathrm{Lt} \text {; (3) } 500001-1000000 \mathrm{Lt} \text {; (4) } 1000001-5 \\
000000 \mathrm{Lt} \text {; (5) more than } 5000000 \mathrm{Lt} \text {. }\end{array}$ & 388 & 3.00 & 1.39 \\
\hline \multicolumn{5}{|c|}{ 年 } \\
\hline Taxes & $\begin{array}{l}\text { One if 'taxes are too high' is considered one of the tree most } \\
\text { important business barrier, zero otherwise. }\end{array}$ & 368 & 0.63 & 0.48 \\
\hline Corruption & $\begin{array}{l}\text { One if 'corruption at the national level' is considered one of } \\
\text { the three most important business barrier, zero otherwise. }\end{array}$ & 368 & 0.16 & 0.37 \\
\hline \multicolumn{5}{|c|}{ (1) } \\
\hline Retail trade & $\begin{array}{l}\text { One if the business is engaged in retail trade, zero } \\
\text { otherwise. }\end{array}$ & 396 & 0.25 & 0.43 \\
\hline Wholesale trade & $\begin{array}{l}\text { One if the business is engaged in wholesale trade, zero } \\
\text { otherwise. }\end{array}$ & 396 & 0.15 & 0.36 \\
\hline Busin. services. & $\begin{array}{l}\text { One if the business is engaged in business services, zero } \\
\text { otherwise. }\end{array}$ & 396 & 0.14 & 0.35 \\
\hline Other services & $\begin{array}{l}\text { One if the business is engaged in other service activities } \\
\text { besides business services, zero otherwise. }\end{array}$ & 396 & 0.17 & 0.38 \\
\hline Dependent Variables & Characteristic & $\mathbf{N}$ & Mean & SD \\
\hline $\begin{array}{l}\text { Growth expectations } \\
\text { (using four ranks) }\end{array}$ & $\begin{array}{l}\text { Ordinal variable indicating the respondent's growth } \\
\text { aspirations in the next five years. Four categories: (1) } \\
\text { decrease turnover or employment; (2) the same or don't } \\
\text { know; (3) increase turnover, but not employment; (4) } \\
\text { increase employment and turnover. }\end{array}$ & 393 & 3.08 & 0.98 \\
\hline $\begin{array}{l}\text { Growth expectations } \\
\text { (using three ranks) }\end{array}$ & $\begin{array}{l}\text { Ordinal variable indicating the respondent's growth } \\
\text { aspirations in the next five years. Modified to three } \\
\text { categories: (1) the same or don't know or decrease turnover } \\
\text { or employment; (2) increase turnover, but not employment; } \\
\text { (3) increase employment and turnover. }\end{array}$ & 393 & 2.81 & 1.32 \\
\hline $\begin{array}{l}\text { Growth expectations } \\
\text { (positive employment } \\
\text { growth as binary } \\
\text { outcome) }\end{array}$ & $\begin{array}{l}\text { One if the respondent plans to increase employment in the } \\
\text { next five years, zero otherwise. }\end{array}$ & 399 & 0.46 & 0.50 \\
\hline
\end{tabular}




\section{DAVIDSON INSTITUTE WORKING PAPER SERIES - Most Recent Papers}

The entire Working Paper Series may be downloaded free of charge at: www.wdi.bus.umich.edu

CURRENT AS OF 10/21/2004

\begin{tabular}{|c|c|c|}
\hline Publication & Authors & Date \\
\hline $\begin{array}{l}\text { No. 723: Which entrepreneurs expect to expand their businesses? } \\
\text { Evidence from survey data in Lithuania }\end{array}$ & $\begin{array}{l}\text { Ruta Aidis and Tomasz } \\
\text { Mickiewicz }\end{array}$ & Oct. 2004 \\
\hline No. 722: Russia from Bust to Boom: Oil, Politics or the Ruble? & $\begin{array}{l}\text { Bruno Merlevede and Koen } \\
\text { Schoors }\end{array}$ & Oct. 2004 \\
\hline No. 721: Distance to the Efficiency Frontier and FDI Spillovers & $\begin{array}{l}\text { Klara Sabirianova Peter, Jan } \\
\text { Svejnar, and Katherine Terrell }\end{array}$ & Sept. 2004 \\
\hline $\begin{array}{l}\text { No. 720: An Analysis of Gender Wage Differentials in Russia from } \\
\text { 1996-2002 }\end{array}$ & Rita Hansberry & Sept. 2004 \\
\hline $\begin{array}{l}\text { No. 719: Returns to Schooling in Russia and Ukraine: } \\
\text { A Semiparametric Approach to Cross-Country Comparative Analysis }\end{array}$ & $\begin{array}{l}\text { Klara Sabirianova Peter and } \\
\text { Yuriy Gorodnichenko }\end{array}$ & Sept 2004 \\
\hline $\begin{array}{l}\text { No. 718: The emergence of large shareholders in mass privatized } \\
\text { firms: Evidence from Poland and the Czech Republic }\end{array}$ & Irena Grosfeld and Iraj Hashi & Aug. 2004 \\
\hline $\begin{array}{l}\text { No. 717: Wage Determination Under Communism and In Transition: } \\
\text { Evidence from Central Europe }\end{array}$ & $\begin{array}{l}\text { Swati Basu, Saul Estrin and Jan } \\
\text { Svejnar }\end{array}$ & Aug. 2004 \\
\hline No. 716: The Evolution of Cross-Region Price Distribution in Russia & Konstantin Gluschenko & July 2004 \\
\hline $\begin{array}{l}\text { No. 715: Languages in the European Union: The Quest for Equality and } \\
\text { its Cost }\end{array}$ & $\begin{array}{l}\text { Jan Fidrmuc and Victor } \\
\text { Ginsburgh }\end{array}$ & July 2004 \\
\hline $\begin{array}{l}\text { No. 714: Voice of the Diaspora: An Analysis of Migrant Voting } \\
\text { Behavior }\end{array}$ & Jan Fidrmuc and Orla Doyle & July 2004 \\
\hline $\begin{array}{l}\text { No. 713: International Coercion, Emulation and Policy Diffusion: } \\
\text { Market-Oriented Infrastructure Reforms, 1977-1999 }\end{array}$ & $\begin{array}{l}\text { Witold J. Henisz and Bennet A. } \\
\text { Zelner and Mauro F. Guillen }\end{array}$ & July 2004 \\
\hline $\begin{array}{l}\text { No. 712: Votes and Vetoes: The Political Determinants of Commercial } \\
\text { Openness }\end{array}$ & $\begin{array}{l}\text { Witold J. Henisz and Edward D. } \\
\text { Mansfield }\end{array}$ & July 2004 \\
\hline $\begin{array}{l}\text { No. 711: Interest Groups, Veto Points and Electricity Infrastructure } \\
\text { Deployment }\end{array}$ & $\begin{array}{l}\text { Witold J. Henisz and Bennet A. } \\
\text { Zelner }\end{array}$ & July 2004 \\
\hline $\begin{array}{l}\text { No. 710: Firms' Price Markups and Returns to Scale in Imperfect } \\
\text { Markets: Bulgaria and Hungary }\end{array}$ & $\begin{array}{l}\text { Rumen Dobrinsky, Gábor Kőrösi, } \\
\text { Nikolay Markov, and László } \\
\text { Halpern }\end{array}$ & July 2004 \\
\hline Growth Pact from the Perspective & Gábor Orbán and György Szapáry & July 2004 \\
\hline $\begin{array}{l}\text { No. 708: Contract Violations, Neighborhood Effects, and Wage Arrears } \\
\text { in Russia }\end{array}$ & $\begin{array}{l}\text { and Klara } \\
\text { eter }\end{array}$ & July 2004 \\
\hline $\begin{array}{l}\text { No. 707: Determinants of Employment Growth at MNEs: Evidence } \\
\text { from Egypt, India, South Africa and Vietnam }\end{array}$ & $\begin{array}{l}\text { ar Bhaumik, Saul } \\
\text { laus Meyer }\end{array}$ & July 2004 \\
\hline $\begin{array}{l}\text { No. 706: Economic Reform in Tanzania and Vietnam: A Comparative } \\
\text { Commentary }\end{array}$ & $\begin{array}{l}\text { Brian Van Arkadie and Do Duc } \\
\text { Dinh }\end{array}$ & June 2004 \\
\hline $\begin{array}{l}\text { No. 705: Beliefs about Exchange-Rate Stability: Survey Evidence } \\
\text { from the Currency Board in Bulgaria }\end{array}$ & $\begin{array}{l}\text { Neven T. Valev and John A. } \\
\text { Carlson }\end{array}$ & June 2004 \\
\hline No. 704: Returns to Schooling in China Under Planning and Reform & $\begin{array}{l}\text { Belton M. Fleisher and Xiaojun } \\
\text { Wang }\end{array}$ & June 2004 \\
\hline $\begin{array}{l}\text { No. 703: Return to Skills and the Speed of Reforms: Evidence from } \\
\text { Central and Eastern Europe, China and Russia }\end{array}$ & $\begin{array}{l}\text { Belton M. Fleisher, Klara } \\
\text { Sabirianova Peter, and Xiaojun } \\
\text { Wang }\end{array}$ & June 2004 \\
\hline $\begin{array}{l}\text { No. 702: What Makes Small Firms Grow? Finance, Human Capital, } \\
\text { Technical Assistance, and the Business Environment in Romania }\end{array}$ & $\begin{array}{l}\text { J. David Brown, John S. Earle } \\
\text { and Dana Lup }\end{array}$ & May 2004 \\
\hline $\begin{array}{l}\text { No. 701: The Effects of Multiple Minimum Wages Throughout the } \\
\text { Labor Market }\end{array}$ & $\begin{array}{l}\text { T. H. Gindling and Katherine } \\
\text { Terrell }\end{array}$ & May 2004 \\
\hline No. 700: Minimum Wages, Inequality and Globalization & $\begin{array}{l}\text { T. H. Gindling and Katherine } \\
\text { Terrell }\end{array}$ & May 2004 \\
\hline No. 699: Self-Selection and Earnings During Volatile Transition & Ralitza Dimova and Ira Gang & May 2004 \\
\hline No. 698: Ecology and Violence: The Environmental Dimensions c & $\begin{array}{l}\text { Timothy L. Fort and Cindy A. } \\
\text { Schipani }\end{array}$ & May 2004 \\
\hline
\end{tabular}

